\title{
Solanum tuberosum L. cv Hongyoung extract inhibits 2,4-dinitrochlorobenzene-induced atopic dermatitis in NC/Nga mice
}

\author{
MYUNG AH KANG ${ }^{1}$ and SE-YOUNG CHOUNG ${ }^{1,2}$ \\ Departments of ${ }^{1}$ Life and Nanopharmaceutical Science of Pharmacy and ${ }^{2}$ Preventive Pharmacy and Toxicology, \\ College of Pharmacy, Kyung Hee University, Seoul 130-701, Republic of Korea
}

Received July 7, 2015; Accepted June 21, 2016

DOI: $10.3892 / \mathrm{mmr} .2016 .5595$

\begin{abstract}
Solanum tuberosum L. cv Hongyoung (SH) is a widely consumed anthocyanin-rich food and medicinal plant, which possesses anti-inflammatory and anti-allergic activities. The present study aimed to examine the inhibitory effects of SH extract on atopic dermatitis (AD)-like skin lesions induced by the topical application of 2,4-dinitrochlorobenzene (DNCB) in NC/Nga mice. SH extract was orally administered to the DNCB-treated NC/Nga mice. The anti-AD effects of $\mathrm{SH}$ extract were examined by measuring symptom severity; ear thickness; scratching behavior; serum levels of immunoglobulin (Ig)E; T-helper (Th)1, Th2 and Th17 cytokine levels in the spleen; mRNA expression levels of inflammatory cytokines and chemokines; and tissue infiltration of inflammatory cells. The results demonstrated that $\mathrm{SH}$ extract inhibited the development of AD-like lesions, and reduced $\operatorname{IgE}$ levels and the production of cytokines. Furthermore, SH extract significantly suppressed the expression of AD-associated mRNAs in lesional skin. Histological alterations in the AD-like lesions were visualized using hematoxylin and eosin, and toluidine blue staining in the DNCB-treated group; the alterations were attenuated following SH treatment. In addition, thickening of the epidermis and accumulation of inflammatory cells in the DNCB-treated mice were suppressed by SH treatment. These results suggested that $\mathrm{SH}$ extract may suppress the development of AD symptoms through modulation of the Th1 and $\mathrm{Th} 2$ responses.
\end{abstract}

Correspondence to: Professor Se-Young Choung, Department of Preventive Pharmacy and Toxicology, College of Pharmacy, Kyung Hee University, 73 Kyungheedae-ro 26-gil, Dongdaemun-gu, Seoul 130-701, Republic of Korea

E-mail: sychoung@khu.ac.kr

Key words: atopic dermatitis, Solanum tuberosum L. cv Hongyoung, IgE, Th1/Th2, 2,4-dinitrochlorobenzene

\section{Introduction}

Atopic dermatitis (AD) is a relapsing skin inflammatory disease with acute and chronic phases, which is characterized by acute pruritus and eczema (1). Skin inflammation is caused by complex interactions between genetic, environmental, pharmacological, psychological, immunological and skin barrier dysfunction factors (2). The prevalence of AD is rapidly increasing in industrialized countries, particularly among children (3). The immunological mechanism underlying AD remains to be fully elucidated; however, a study regarding AD immunopathology have demonstrated that AD is highly correlated with immune system dysregulation (4).

In human $\mathrm{AD}$, skin inflammation occurs when the skin is damaged by pruritus-induced scratching, and is followed by rapidly developing erythema, hemorrhage, scarring, dryness, and skin lesion hyperplasia (5). This type of dermatitis is associated with increased production of proinflammatory cytokines, which activate various types of immune cell, consequently initiating the AD inflammatory cycle. Interleukin (IL)-4, IL-5 and IL-13, which are produced by T-helper (Th) 2 cells, may have important roles in the acute phase of AD (6). Th2 cells mediate immunoglobulin (Ig)E production via the release of cytokines and chemical mediators (7). Increased IgE levels are a hallmark of $\mathrm{AD}$, and increased IL-4 levels are associated with IgE elevation in B cells. IgE is released from B cells and binds to mast cells, which release various biological mediators, particularly histamine, in IgE-mediated AD (2).

Although Th 2 cytokines are dominant in the acute phase of $\mathrm{AD}$, Th1 cytokines, including interferon (IFN)- $\gamma$ and IL-12, are expressed and are associated with the pathogenesis of $\mathrm{AD}$ in the chronic phase (8). Recently, T regulatory (Treg) cells, which are a subtype of $\mathrm{T}$ cell, have been reported to have an important role in the modulation of allergic and autoimmune responses, and are characterized by the dominant transcription of forkhead box P3, a forkhead/winged helix transcription factor gene, which is the fingerprint of native Treg cells (9). Th1/Th2 polarization is well-defined in murine models induced by artificial immunization. Specifically, AD is an allergic disease that results from dermal inflammation, a hallmark characteristic of which is a disruption in the immunological balance between Th1 and Th 2 cells (10). It has previously been 
suggested that IL-17-producing CD4+ ${ }^{+}$-helper cells (Th17) participate in the pathogenesis of AD (11). In Th1-mediated chronic inflammatory disease with epidermal hyperplasia, IL-17 has been reported to be associated with allergen-specific immune responses (12).

At present, steroid therapy is widely applied for the treatment of $\mathrm{AD}$; however, since this treatment causes severe side effects, including immunosuppression, stretch marks, thinning of the skin, and epidermal barrier dysfunction, it cannot be used for long periods of time (13). Therefore, a study investigated the potential of natural substances for the treatment of patients with $\mathrm{AD}(14)$.

Solanum tuberosum L. cv Hongyoung (SH) is a variety of potato with red skin and flesh. This variety possesses numerous anthocyanins, which the general potato does not (15); their high anthocyanin content is due to the pigments that are responsible for their color (16). Anthocyanin concentration varies in the large range of potatoes, and is correlated with the degree of pigmentation in colored potato flesh. It has previously been reported that a high intake of anthocyanin-rich food is associated with health protective effects, and a reduced risk of diabetes, arthritis and cancer, partially due to their antioxidant and anti-inflammatory activities (17). The present study aimed to determine the effects of a water extract of $\mathrm{SH}$ on the skin symptoms of $\mathrm{NC} / \mathrm{Nga}$ mice treated with a repeated topical application of 2,4-dinitrochlorobenzene (DNCB). The inhibitory effects of SH extract were detected on the development of $\mathrm{AD}$ in vivo.

\section{Materials and methods}

Reagents. RPMI 1640 medium, penicillin, streptomycin, phosphate-buffered saline (PBS) and fetal bovine serum (FBS) were purchased from Hyclone (GE Healthcare Life Sciences, Logan, UT, USA).

DNCB, concanavalin A (Con A) and prednisolone were obtained from Sigma-Aldrich (St. Louis, MO, USA). Mouse enzyme-linked immunosorbent assay (ELISA) kit for IgE was obtained from Shibayagi (Shibukawa, Japan). Mouse ELISA kits for IL-4, IgG1 and IgG2 were purchased from Enzo Life Sciences (UK) Ltd. (Exeter, UK). IL-13, IFN- $\gamma$, and IL-17 ELISA kits were purchased from eBioscience, Inc. (San Diego, CA, USA). The ELISA kit for IL-12 was purchased from Bioo Scientific (Austin, TX, USA). TRIzol ${ }^{\circledR}$ reagent was purchased from Invitrogen (Thermo Fisher Scientific, Inc., Waltham, MA, USA). Oligo dT and MMLV transcriptase were obtained from Promega Corporation (Madison, WI, USA), and SYBR Green supermix was purchased from Takara Bio Inc. (Otsu, Japan).

Preparation of SH extracts. SH was supplied by Hamyang-gun Agricultural Development \& Technology Center (Hamyang, South Korea). SH was cut into slices $(1 \mathrm{~cm})$, and treated with $80 \%$ aqueous ethanol for $24 \mathrm{~h}$ at room temperature. This procedure was repeated twice. After filtration, the solvent was vaporized under low pressure, and the filtrate was diluted with distilled water. After freeze-drying, the resulting extract powder was maintained at $-70^{\circ} \mathrm{C}$ until further use.

High-performance liquid chromatography (HPLC) analysis. The HPLC instrument used consisted of Waters HPLC (separation module 2690), photodiode array detector 2996 running Empower software, and Atlantis T3 C18 column $(4.6 \times 150 \mathrm{~mm}, 5 \mu \mathrm{m})$ (Waters Corporation, Milford, MA, USA). The mobile phase consisted of acidified acetonitrile with formic acid $(0.1 \%$, solvent $\mathrm{A})$ and acidified water with formic acid $(0.1 \%$, solvent $\mathrm{B})$, which were eluted at a flow rate of $1.0 \mathrm{ml} / \mathrm{min}$. The gradient program for $\mathrm{SH}$ was $0-10 \mathrm{~min}$, $10 \%$ solvent $\mathrm{A} ; 60$ min, $40 \%$ solvent $\mathrm{A} ; 80 \mathrm{~min}, 80 \%$ solvent A; $81 \mathrm{~min}, 100 \%$ solvent A. Briefly, $30 \mathrm{mg} \mathrm{SH}$ extract powder was dissolved in $1 \mathrm{ml} 100 \%$ methanol, and was adjusted to pH 2.0 using formic acid. A $10 \mu 1$ aliquot of the sample solution was injected into the HPLC system following filtration with a $0.45 \mu \mathrm{m}$ syringe filter (EMD Millipore, Bedford, MA, USA). HPLC analysis was performed at $520 \mathrm{~nm}$ at room temperature. Identification of major peaks was performed according to a HPLC-electrospray ionization (ESI)-mass spectrometry (MS) study. AccuTOF ${ }^{\circledR}$ single-reflectron time-of-flight mass spectrometer was equipped with an ESI source (JEOL USA, Inc., Peabody, MA, USA) and was operated with MassCenter system version 1.3.7b (JEOL USA, Inc.). MS spectra obtained in the positive ion mode were more informative than those obtained from the negative ion mode; therefore, acquisition was performed in the positive ion mode. The parameters were as follows: Orifice $1=30 \mathrm{~V}$; ring lens and orifice $2=15$ and $10 \mathrm{~V}$, respectively. The ion guide potential and detector voltage were set to 2,200 V. ESI parameter needle electrode $=1,500 \mathrm{~V}$; nitrogen gas was used as a nebulizer, flow rate $1-3 \mathrm{l} / \mathrm{min}$, desolvating chamber temperature $=250^{\circ} \mathrm{C}$, orifice 1 temperature $=80^{\circ} \mathrm{C}$. Mass scale calibration was accomplished using the YOKUDELNA calibration kit (JEOL Ltd., Tokyo, Japan) for accurate mass measurements.

Animals. Male NC/Nga mice (age, 4 weeks; weight, 16 g) were obtained from SLC (SLC, Inc., Shizuoka, Japan) and were stored in standard cages (individually ventilated cages) at $23 \pm 3^{\circ} \mathrm{C}$ in an atmosphere containing $55 \pm 5 \%$ humidity. The mice were maintained under a 12/12 h light/dark cycle in specific pathogen-free conditions at the Animal Research Center at Kyung Hee University (Seoul, North Korea). The mice were allowed ad libitum access to Purina rodent chow (Raonbion, Seoul, Korea) and tap water. All mice were acclimated for 7 days prior to commencement of the experiments. Experimental protocols were performed in accordance with the Standard Operating Procedure recognized by the National Institutes of Health Guide for the Care and Animal Welfare Act and Use of Laboratory Animals (Approval number KHP-2014-04-1-R1). The study was approved by the ethics committee of the Department of Life and Nanopharmaceutical Science of Pharmacy, College of Pharmacy, Kyung Hee University (Seoul, Korea).

Treatment. To induce AD-like skin lesions, hair on the ears and dorsal skin of NC/Nga mice was removed using hair removal cream and an electric shaver twice a week. On the subsequent day, $200 \mu \mathrm{l} 1 \%$ DNCB solution (dissolved in 2:3 mixture of acetone and olive oil) was applied to the shaved dorsal area $\left(\sim 8 \mathrm{~cm}^{2}\right)$ (Fig. 1). On day 4 after the initial sensitization, $200 \mu \mathrm{l}$ $1 \%$ DNCB mixture was applied to the shaved dorsal area for the second sensitization. On day 7 after the initial sensitization, the dorsal skin and ears of the mice were challenged with 
Table I. Experimental design.

\begin{tabular}{|c|c|}
\hline Group $(n=8)$ & Treatment \\
\hline Normal control & $0.5 \% \mathrm{CMC}$ \\
\hline Negative control & $0.4 \% \mathrm{DNCB}+0.5 \% \mathrm{CMC}$ \\
\hline Positive control & $0.4 \% \mathrm{DNCB}+$ Prednisolone $3 \mathrm{mg} / \mathrm{kg} \cdot \mathrm{bu}$ \\
\hline SH extract 75 & $0.4 \% \mathrm{DNCB}+\mathrm{SH} 75 \mathrm{mg} / \mathrm{kg} \cdot \mathrm{bw}$ \\
\hline SH extract 150 & $0.4 \% \mathrm{DNCB}+\mathrm{SH} 150 \mathrm{mg} / \mathrm{kg} \cdot \mathrm{bw}$ \\
\hline SH extract 300 & $0.4 \% \mathrm{DNCB}+\mathrm{SH} 300 \mathrm{mg} / \mathrm{kg} \cdot \mathrm{bw}$ \\
\hline
\end{tabular}

SH, Solanum tuberosum L. cv Hongyoung extract; CMC, carboxymethyl cellulose; DNCB, 2,4-dinitrochlorobenzene; bw, body weight.

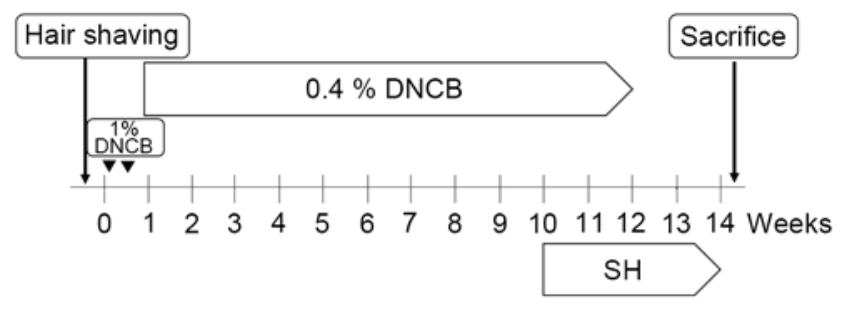

Figure 1. Schematic diagram of the experimental protocol in mice. To induce atopic dermatitis (AD)-like immunological alterations and skin lesions, 2,4-dinitrochlorobenzene (DNCB) was applied to the dorsal skin and ears. Following complete removal of dorsal hairs within a $\sim 8 \mathrm{~cm}^{2}$ area, $200 \mu 1$ $1 \%$ DNCB was applied to the dorsal skin and ears for the first sensitization. Four days later, the mice were treated once more with $200 \mu 11 \%$ DNCB for the second sensitization. A week after the first sensitization, mice were divided into six groups ( $\mathrm{n}=8$ /group). The dorsal skin and ears were challenged with $150 \mu \mathrm{l}$ $0.4 \%$ DNCB solution three times a week for 9 weeks. A total of 9 weeks after AD induction, Solanum tuberosum L. cv Hongyoung (SH) extract (75, 150 or $300 \mathrm{mg} / \mathrm{ml}$ ) was orally administered seven times a week for 4 weeks. Control and DNCB-treated mice were administered $0.5 \%$ carboxymethyl cellulose (CMC). Animals were sacrificed 56 days after the first application of DNCB.

$150 \mu \mathrm{l} 0.4 \%$ DNCB mixture (0.4\% DNCB dissolved in a 3:1 mixture of acetone and olive oil). After the first challenge, $0.4 \%$ DNCB solution was repeatedly applied to the dorsal skin and ears 3 times a week for 9 weeks. The mice were allocated to six groups ( $\mathrm{n}=8 /$ group): Normal control group, negative control group, positive control group, and $\mathrm{SH}$ extract-treated groups, which received 75,150 or $300 \mathrm{mg} / \mathrm{kg} \cdot$ body weight (bw) SH extract. SH extract was orally administered daily for 4 weeks, starting 9 weeks after sensitization with $1 \%$ DNCB. The normal and negative control groups were treated with $0.5 \%$ carboxymethyl cellulose (CMC), and the positive control group was administered prednisolone $(3 \mathrm{mg} / \mathrm{kg} \cdot \mathrm{bw})$ dissolved into $0.5 \%$ CMC (Table I).

Scoring of skin dermatitis severity and ear thickness. Following sample treatment, right ear thickness was gauged three times per week using a thickness gauge (Mitutoyo Corporation, Tokyo, Japan). Total clinical severity score was evaluated three times a week. The extent of dryness, lichenification, excoriation, erythema/edema and erosion was scored as follows: 0 , no symptoms; 1 , mild symptoms; 2 , moderate symptoms; and 3 , severe symptoms. The total skin score was defined as the sum of the individual scores (18).
Established scratching behavior. Scratching behavior was observed following completion of the treatments. Specifically, scratching was counted three times a week. Mice from each group were placed into a new cage for $1 \mathrm{~h}$ of habituation. The number of times a mouse scratched the dorsal skin lesion within a period of 30 min was counted (19). Scratching behavior was scored from 0 to 4 , as follows: 0 , no scratching; 2 , scratching shorter than $1.5 \mathrm{sec}$; and 4, scratching longer than $1.5 \mathrm{sec}$. The total scratching behavior number was calculated as the sum of the individual scores (20).

Plasma Ig analysis. The immunological response during DNCB-induced AD was monitored by measuring the serum levels of $\operatorname{IgE}, \operatorname{IgG} 1$ and $\operatorname{IgG} 2 \mathrm{a}$. The plasma levels of IgE were measured using the mouse IgE ELISA kit, and IgG1 and IgG2a levels were measured using mouse IgG1 and IgG2a ELISA kits. The ELISAs were performed according to manufacturers' protocols.

Cytokine production by splenocytes. Each group of mice was sacrificed by overdose of diethyl ether, and the spleens from each mouse were obtained. Spleens isolated from $\mathrm{NC} / \mathrm{Nga}$ mice were crushed using a cell strainer (BD Biosciences, Franklin Lakes, NJ, USA) and were then resuspended in culture medium (RPMI-1640 supplemented with 10\% FBS, $50 \mathrm{mg} / \mathrm{ml}$ streptomycin and $100 \mathrm{U} / \mathrm{ml}$ penicillin). Splenocytes were cultured in 24-well plates at a cell density of $1 \times 10^{6}$ cells $/ \mathrm{ml}$. Briefly, splenocytes were treated with $5 \mu \mathrm{g} / \mathrm{ml}$ Con $\mathrm{A}$ and were incubated in a $5 \% \mathrm{CO}_{2}$ incubator for $72 \mathrm{~h}$ at $37^{\circ} \mathrm{C}$. Subsequently, the supernatants were harvested to determine the levels of IL-4, IL-13, IFN- $\gamma$, IL-12 and IL-17A using ELISA kits in accordance with the manufacturers' protocols.

Reverse transcription-quantitative polymerase chain reaction (PCR) analysis. Tissues were homogenized and total RNA was isolated from the right ear lesional tissue using TRIzol ${ }^{\circledR}$ reagent. Isolated RNA underwent reverse transcription and was amplified by PCR using MMLV reverse transcriptase (Promega Corporation), 5X buffer, $10 \mathrm{mM}$ deoxyribonucleotide triphosphates mix, RNase inhibitor and Oligo dT at $42^{\circ} \mathrm{C}$ for $1 \mathrm{~h}, 94^{\circ} \mathrm{C}$ for $5 \mathrm{~min}$ and $4^{\circ} \mathrm{C}$ for $1 \mathrm{~h}$. Subsequently, equal amounts of cDNA were mixed with $5 \mathrm{pM}$ primer and SYBR Green supermix and were analyzed using an ABI StepOnePlus Real-Time PCR machine (Applied Biosystems; Thermo Fisher Scientific, Inc.). The primer sets used in the PCR amplification are presented in Table II. The reactions were set up in a total volume of $20 \mu \mathrm{l}$ using $0.5 \mu \mathrm{l}$ of cDNA and $10 \mu \mathrm{l}$ of 2X Taqman probe mix (Applied Biosystems). Amplification was performed under the following cycling conditions: $95^{\circ} \mathrm{C}$ for $10 \mathrm{~min}$, followed by 40 cycles of $95^{\circ} \mathrm{C}$ for $15 \mathrm{sec}, 60^{\circ} \mathrm{C}$ for $1 \mathrm{~min}$, and $72^{\circ} \mathrm{C}$ for $20 \mathrm{sec}$. The mRNA expression levels of each gene were normalized to the levels of $\beta$-actin. According to the comparative $\mathrm{Cq}$ method, gene expression was normalized to the expression of the housekeeping $\beta$-actin. The gene expression level, normalized to the housekeeping gene and relative to the control sample, was calculated as the $2^{-\Delta \Delta \mathrm{Cq}}(21)$.

Histological analysis. After the mice were sacrificed, the dorsal skin and one ear from each mouse was fixed in $10 \%$ buffered neutral formalin. Paraffin-embedded dorsal skin 
Table II. Primer sequences and reaction conditions for quantitative polymerase chain reaction.

\begin{tabular}{|c|c|c|}
\hline Gene & Primer sequence $\left(5^{\prime} \rightarrow 3^{\prime}\right)$ & Temperature $\left({ }^{\circ} \mathrm{C}\right)$ \\
\hline \multirow[t]{2}{*}{$\beta$-actin } & (F) CCC AAC TTG ATG TAT GAA GG & 55 \\
\hline & (R) TTG TGT AAG GTA AGG TGT GC & 55 \\
\hline \multirow[t]{2}{*}{ IL-4 } & (F) GTC TGC TGT GGC ATA TTC TG & 57 \\
\hline & (R) GGC ATT TCT CAT TCA GAT TC & 53 \\
\hline \multirow[t]{2}{*}{ IL-5 } & (F) GGC TAC ACA GAG AAA CCC TGT & 59 \\
\hline & (R) CAT GCA TAC ACA GGT AGT TCA & 55 \\
\hline \multirow[t]{2}{*}{ IL-12 } & (F) CAC CAG CAG CTT CTT CAT CAG A & 60 \\
\hline & (R) CAA TGG CTT CAG CTG CAG GT & 59 \\
\hline \multirow[t]{2}{*}{ IFN- $\gamma$} & (F) CTC TGA GAC AAT GAA CGC TAC ACA CT & 61 \\
\hline & (R) TGG CAG TAA CAG CCA GAA ACA G & 60 \\
\hline \multirow[t]{2}{*}{ CCR3 } & (F) CCC GTA CAA CCT GGT TCT CC & 61 \\
\hline & (R) AAA GAG CCG AAG GTG TTT CC & 57 \\
\hline \multirow[t]{2}{*}{ CCR4 } & (F) TCG CCT TGT TTC AGT CAG G & 57 \\
\hline & (R) CTT GCC ATG GTC TTG GTT TT & 55 \\
\hline \multirow[t]{2}{*}{ Eotaxin-1/CCL11 } & (F) CAC CCT GAA AGC CAT AGT GT & 57 \\
\hline & (R) TGT GTA CCT GGG AAA TTA G & 53 \\
\hline \multirow[t]{2}{*}{ MCP-1 } & (F) TTA AGG CAT CAC AGT CCG AG & 57 \\
\hline & (R) TGA ATG TGA AGT TGA CCC GT & 55 \\
\hline \multirow[t]{2}{*}{ IL-17 } & (F) AAG GCA GCA GCG ATC ATC C & 59 \\
\hline & (R) GGA ACG GTT GAG GTA GTC TGA G & 61 \\
\hline
\end{tabular}

IL, interleukin; IFN- $\gamma$, interferon- $\gamma$; CCR, C-C chemokine receptor; CCL11, C-C motif chemokine ligand 11; MCP-1, monocyte chemoattractant protein-1; F, forward; R, reverse.

samples from the mice were sectioned into $4 \mu \mathrm{m}$ slices, which were then stained with hematoxylin and eosin (H\&E) or toluidine blue for $4 \mathrm{~h}$ at $2-4^{\circ} \mathrm{C}$ in order to measure the number of various inflammatory cells and mast cells, respectively. The sections were examined by light microscopy to assess histological alterations.

Statistical analysis. Data are presented as the mean \pm standard error of the mean. Differences between groups were detected using SPSS 21 (IBM, Armonk, NY, USA) by one-way analysis of variance followed by Tukey's test. $\mathrm{P}<0.05$ was considered to indicate a statistically significant difference.

\section{Results}

HPLC profile of $S H$. To identify the effective compound from $\mathrm{SH}, \mathrm{HPLC}$ analysis was performed at $520 \mathrm{~nm}$. As shown in Fig. 2, the major peak in the total ion chromatogram at 21 min corresponds with the main peak from the HPLC chromatogram. The major anthocyanin was identified by HPLC-ESI-MS and MS/MS using full spectral scan, precursor ion scan, and product ion scan experiments, demonstrated the molecular and aglycone ions at $\mathrm{m} / \mathrm{z} 877,725,433$ and 271 , which indicated the presence of pelargonidin-3-coumaroylrutinoside-5-O-glucoside. The major anthocyanin peak was identified by HPLC-ESI-MS using a full spectral scan, precursor ion scan and product ion scan experiments. The difference in molecular masses of $20 \mathrm{mmu}$ indicated the presence of pelargonidin-3-coumaroylrutinoside-5-O-glucoside. The chemical structure of the anthocyanin is shown in Fig. 2.
Effects of SH extract on DNCB-induced AD-like skin lesions and ear thickness in Nc/Nga mice. To evaluate the effectiveness of SH extract against AD-like skin lesions, post-induction of AD-like skin lesions by DNCB application, the mice were treated with 75,150 or $300 \mathrm{mg} / \mathrm{kg} \mathrm{SH}$ extract daily for 4 weeks. Skin conditions were investigated three times a week for 4 weeks according to dermatitis severity scores. Repeated DNCB application significantly increased dermatitis severity scores, and induced hemorrhage, edema, scarring, dryness and erosion in NC/Nga mice (Fig. 3). As shown in Fig. 4A, DNCB-induced AD symptoms were suppressed by SH extract or prednisolone compared with in the AD group. Repeated application of DNCB also significantly increased ear thickness in mice, as compared with in the normal group. In addition, ear lesions exhibited hyperkeratosis and dermal thickening in the DNCB-treated group compared with in the control group. These symptoms were all suppressed by SH extract and prednisolone treatments (Fig. 4B). These results indicate that $\mathrm{SH}$ extract decreases $\mathrm{AD}$ symptoms in $\mathrm{NC} / \mathrm{Nga}$ mice.

Effects of SH extract on scratching behavior. To investigate the effects of SH extract on scratching behavior, the number of times a mouse scratched the dorsal skin lesion within a period of 30 min was counted $1 \mathrm{~h}$ after sample treatment. As shown in Fig. 4C, the SH-treated and positive control groups exhibited reduced scratching behavior compared with the negative control group. Between weeks 2 and 3, the SH 150 and $300 \mathrm{mg} / \mathrm{kg}$ groups exhibited significantly reduced scratching behavior compared with the AD control 
A

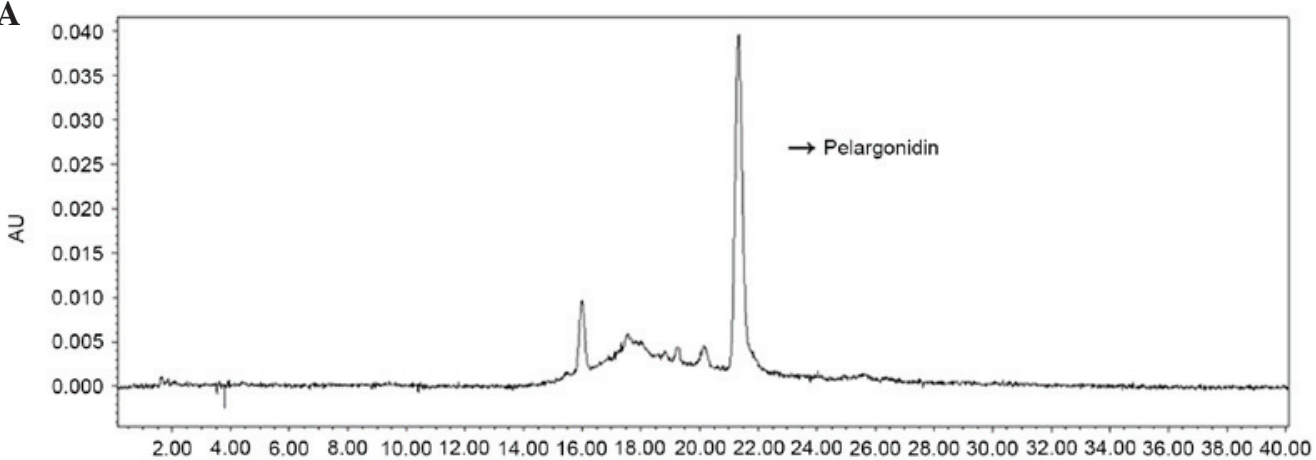

B

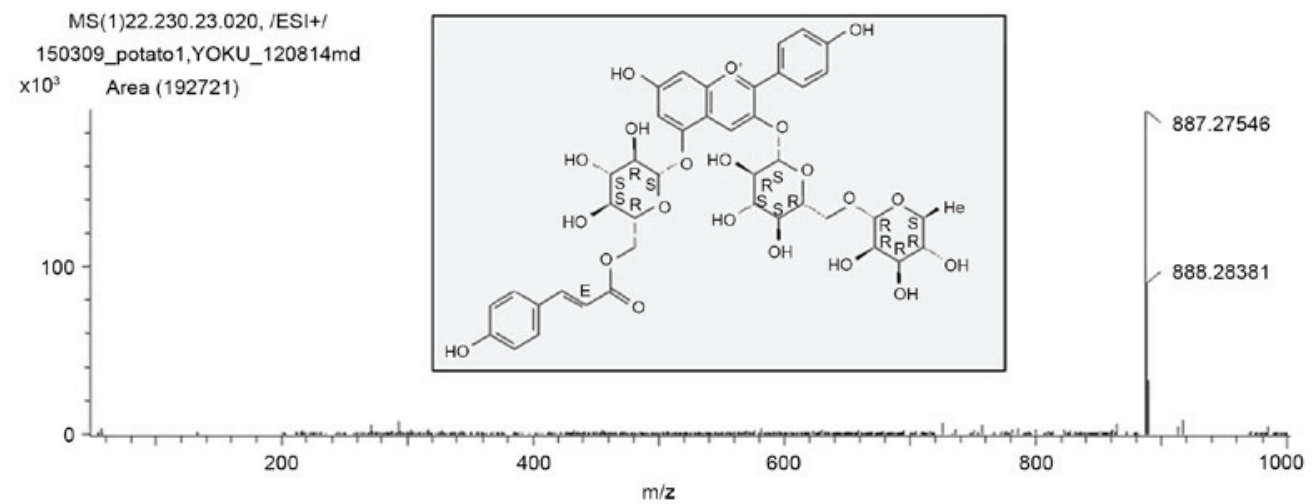

Figure 2. High-performance liquid chromatography (HPLC) chromatogram of Solanum tuberosum L. cv Hongyoung (SH) extract. (A) HPLC chromatographic profile of SH extract at $520 \mathrm{~nm}$. (B) Electrospray ionization-mass spectrometry chromatogram of pelargonidin 3-coumaroylrutinoside-5-O-glucoside and its chemical structure.

A

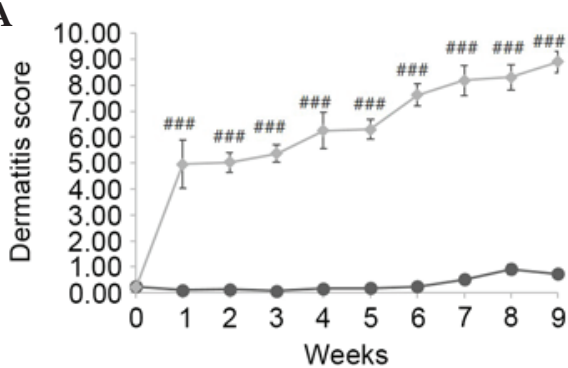

B

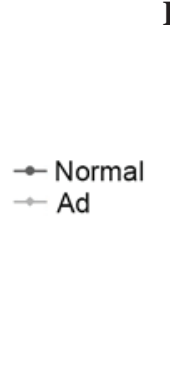

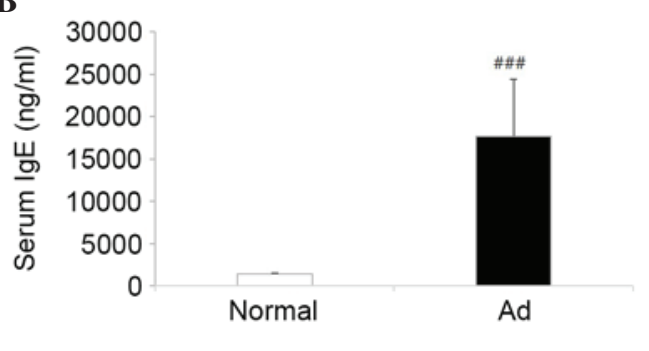

Figure 3. Evaluation of atopic dermatitis (AD)-like symptoms induced by treatment with 2,4-dinitrochlorobenzene. Dermatitis score was assessed once a week for 9 weeks following induction of AD. (A) The dermatitis score was defined as the sum of scores for five clinical criteria: Dryness, lichenification (scaling), excoriation, erythema/edema and erosion. (B) Serum was collected a day after the last treatment with DNCB to measure total immunoglobulin (Ig)E serum levels. Data are presented as the mean \pm standard error of the mean (normal group, $\mathrm{n}=8$; atopic dermatitis group, $\mathrm{n}=40$ ). ${ }^{\# \# \#} \mathrm{P}<0.001 \mathrm{vs}$. the normal group.

group. These results indicate that SH extract and prednisolone decrease AD symptom-like scratching.

Effects of SH extract on serum Ig levels. In addition to clinical features, the levels of $\operatorname{IgE}, \operatorname{IgG} 1$ and $\operatorname{IgG} 2 \mathrm{a}$ were detected in serum samples from $\mathrm{NC} / \mathrm{Nga}$ mice in order to characterize the immunological response during disease progression.

Excessive production of $\operatorname{IgE}$ is associated with disease severity in patients with AD (22). Plasma IgE levels were detected in the mice treated with $\mathrm{SH}$ extract and compared with those of the control group. Mice were treated with 75, 150 or $300 \mathrm{mg} / \mathrm{kg} \mathrm{SH}$ extract and prednisolone daily post-induction of AD-like skin lesions by DNCB application. As shown in Fig. 5A, repeated topical application of DNCB significantly increased the secretion of $\operatorname{IgE}$ compared with in the control group. Conversely, oral administration of SH extract $(75,150$ or $300 \mathrm{mg} / \mathrm{kg}$ ) or prednisolone decreased serum IgE levels by $29,40,45$ and $47 \%$ for 4 weeks, respectively. AD is associated with dysregulation of the Th1/Th2 balance (23). SH extract was able to decrease the serum levels of Th2-mediated IgG1 and increase the levels of Th1-mediated IgG2a. As shown in Fig. 5B and C, DNCB induced increased IgG1 levels, which were decreased following treatment with $\mathrm{SH}$ extract $(75,150$ and $300 \mathrm{mg} / \mathrm{kg}$ ) and prednisolone. In addition, SH extract increased the production of IgG2a. As shown in Fig. 5D, the IgG1/IgG2a ratio was decreased in the $\mathrm{SH}$ extract and positive control groups. These results indicate that SH extract may alleviate AD-like skin symptoms through the upregulation of 

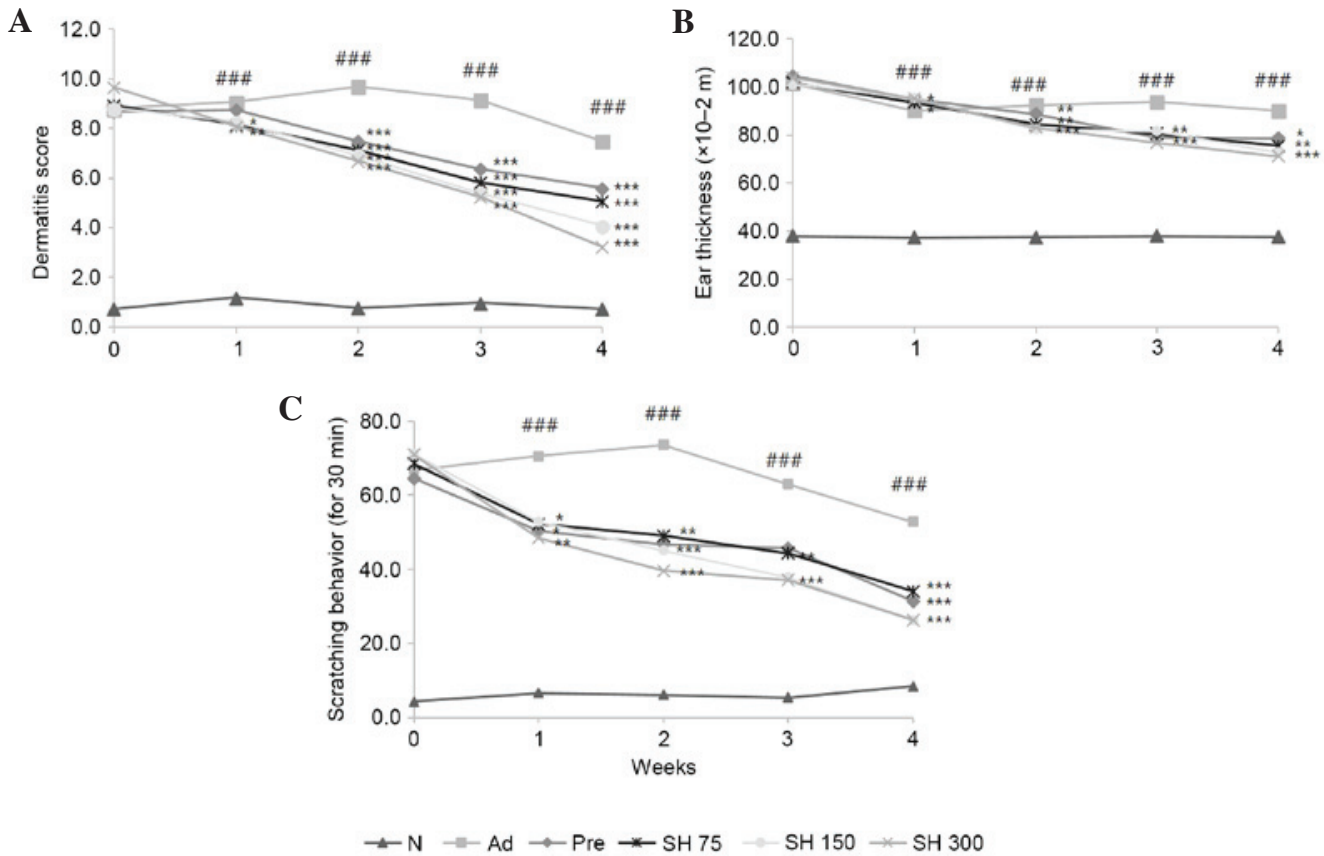

Figure 4. Effects of Solanum tuberosum L. cv Hongyoung extract (SH) on (A) dermatitis score, (B) ear thickness and (C) scratching behavior. (A) Dermatitis score was evaluated as the sum of scores in five clinical symptoms. (B) Ear thickness was measured using a dial thickness gauge. Dermatitis score and ear thickness are presented as the mean \pm standard error of the mean of five mice per group. (C) Scratching behavior within 30 min was counted $1 \mathrm{~h}$ after each treatment, three times a week. Weekly data are presented as the mean \pm standard error of the mean from three days a week. ${ }^{\# \#} \mathrm{P}<0.001 \mathrm{vs.} \mathrm{the} \mathrm{normal} \mathrm{group;}$ ${ }^{*} \mathrm{P}<0.05,{ }^{* *} \mathrm{P}<0.01,{ }^{* * *} \mathrm{P}<0.001$ vs. the atopic dermatitis (AD) group. $\mathrm{N}$, normal control; Pre, prednisolone-treated group.

A

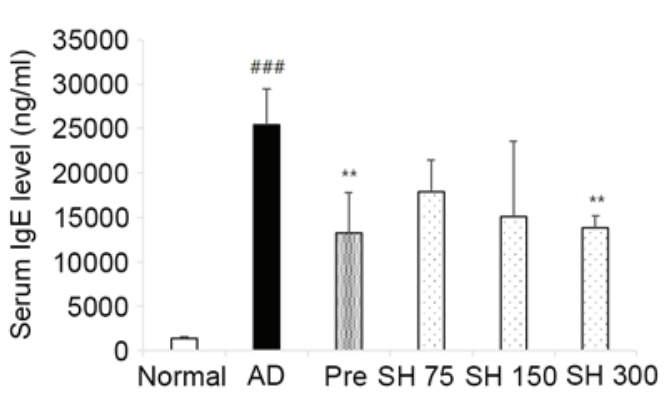

C

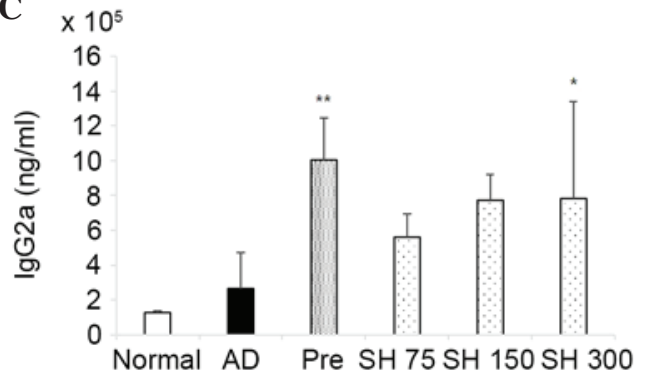

B

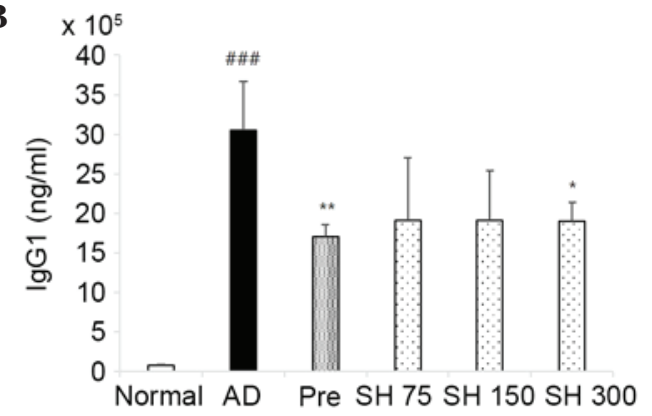

D

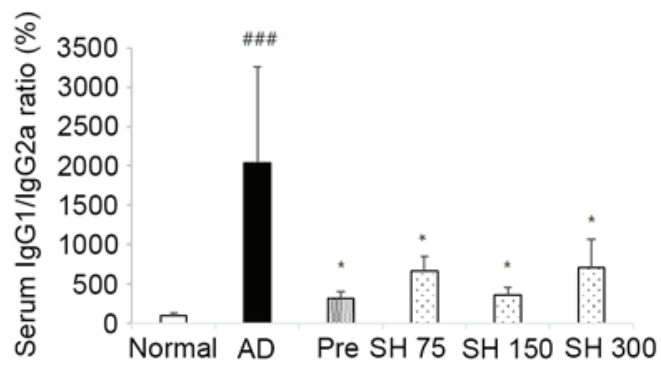

Figure 5. Effects of Solanum tuberosum L. cv Hongyoung extract (SH) on serum (A) immunoglobulin (Ig)E, (B) $\operatorname{IgG} 1$ (C) $\operatorname{IgG} 2 \mathrm{a}$ and (D) $\operatorname{IgG1} / \mathrm{IgG} 2 \mathrm{a}$ ratio levels in NC/Nga mice. After the final sample treatment, serum was collected following sacrifice. Serum levels of (A) $\operatorname{IgE}$, (B) $\operatorname{IgG1}$, (C) $\operatorname{IgG} 2 \mathrm{a}$ were measured using enzyme-linked immunosorbent assay kit. (D) IgG1/IgG2a ratio in serum was determined for each mouse group. Data are presented as the mean \pm standard error of the mean of five mice per group. ${ }^{\# \# \#} \mathrm{P}<0.001$ vs. the normal group; ${ }^{*} \mathrm{P}<0.05,{ }^{* *} \mathrm{P}<0.01$ vs. the AD group. Pre, prednisolone-treated group.

IgG2a (Fig. 5) and the concomitant downregulation of IgE and IgG1.

SH extract suppresses cytokine production in splenocytes. The present study investigated the inhibitory effects of SH extract on DNCB-induced cytokines produced by splenocytes. Spleens were collected from the $\mathrm{NC} / \mathrm{Nga}$ mice treated with $\mathrm{SH}$ extract or prednisolone following sacrifice, and isolated splenocytes were stimulated with $5 \mu \mathrm{g} / \mathrm{ml}$ Con A and incubated for $72 \mathrm{~h}$. Following incubation, the supernatants were collected, and the levels of IL-4 and IL-13 (Th2 cytokines), and IFN- $\gamma$ and IL-12 (Th1 cytokines) were measured in the supernatant using 

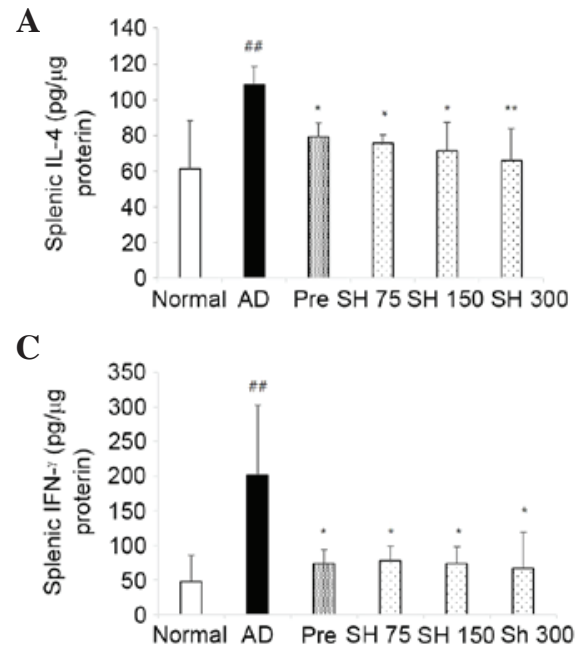

B

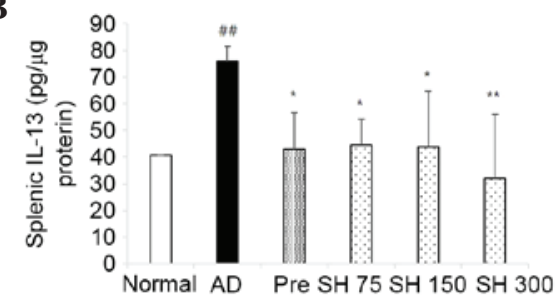

D

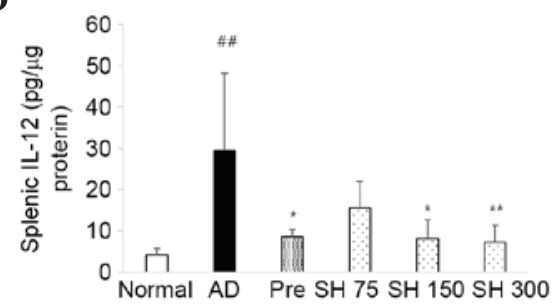

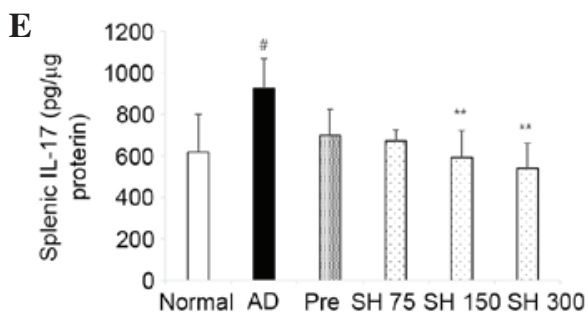

Figure 6. Effects of Solanum tuberosum L. cv Hongyoung extract (SH) on splenic (A) interleukin (IL)-4, (B) IL-13, (C) interferon (IFN)- $\gamma$, (D) IL-12 and (E) IL-17 production. The day after the final treatment, mice were sacrificed and the spleens from each mouse were obtained. Isolated splenocytes were stimulated by concanavalin A and incubated for $72 \mathrm{~h}$. The levels of (A) IL-4, (B) IL-13, (C) IFN- $\gamma$, (D) IL-12 and (E) IL-17 in the supernatant were measured by enzyme-linked immunosorbent assay kits. Data are presented as the mean \pm standard error of the mean from six mice per group. ${ }^{\#} \mathrm{P}<0.05$ and ${ }^{\# \#} \mathrm{P}<0.01 \mathrm{vs}$. the normal group; ${ }^{*} \mathrm{P}<0.05,{ }^{* *} \mathrm{P}<0.01$ vs. the atopic dermatitis (AD) group. Pre, prednisolone-treated group.

A

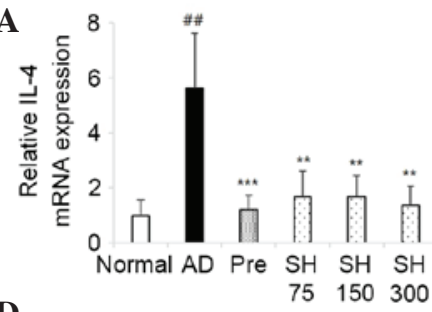

D

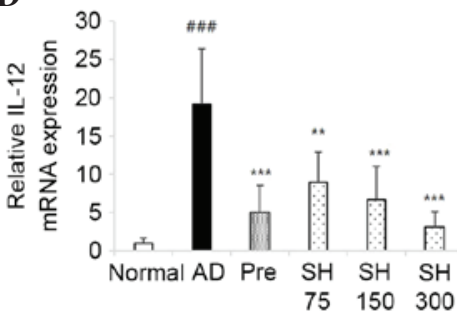

G

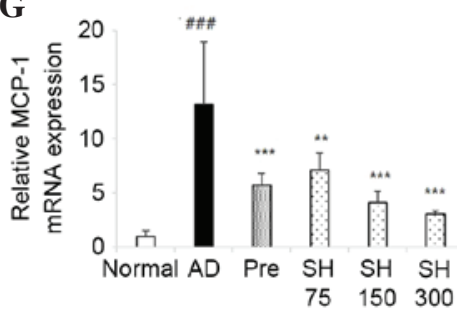

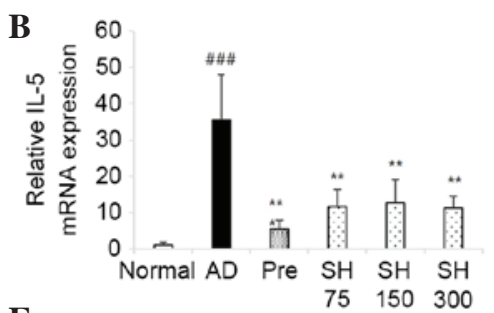

$\mathbf{E}$
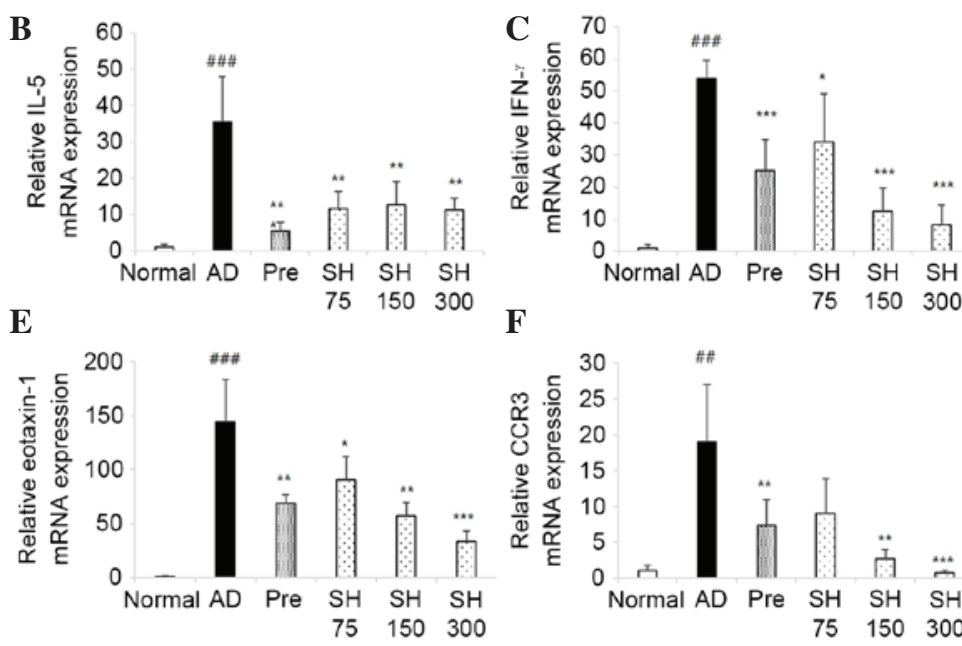

F

$\mathbf{H}$

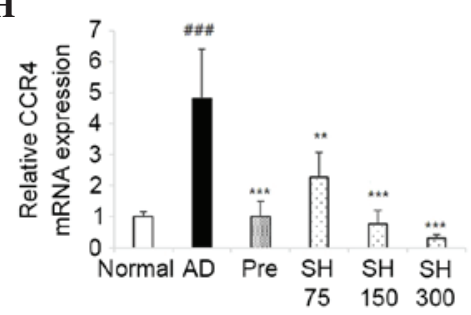

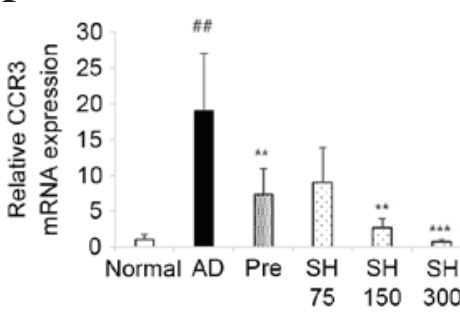

I

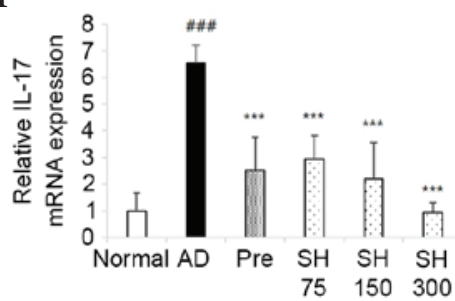

Figure 7. Inhibitory effects of Solanum tuberosum L. cv Hongyoung extract (SH) on 2,4-dinitrochlorobenzene-induced interleukin (IL)-4, IL-5, interferon (IFN)- $\gamma$, IL-12, eotaxin-1, C-C chemokine receptor (CCR)3, monocyte chemoattractant protein (MCP)-1, CCR4 and IL-17 mRNA expression in NC/Nga mice. A total of $24 \mathrm{~h}$ after the final treatment, mice were sacrificed and lesional tissues were obtained. mRNA expression levels of (A) IL-4, (B) IL-5, (C) IFN- $\gamma$, (D) IL-12, (E) eotaxin-1, (F) CCR3, (G) MCP-1, (H) CCR4 and (I) IL-17 were measured by quantitative polymerase chain reaction. Data are presented as the mean \pm standard error of the mean from five mice per group. ${ }^{\#} \mathrm{P}<0.05,{ }^{\# *} \mathrm{P}<0.01$ vs. the normal group; ${ }^{*} \mathrm{P}<0.05,{ }^{* *} \mathrm{P}<0.01,{ }^{* * *} \mathrm{P}<0.001$ vs. the atopic dermatitis (AD) group. Pre, prednisolone-treated group. 
$\mathbf{A}$
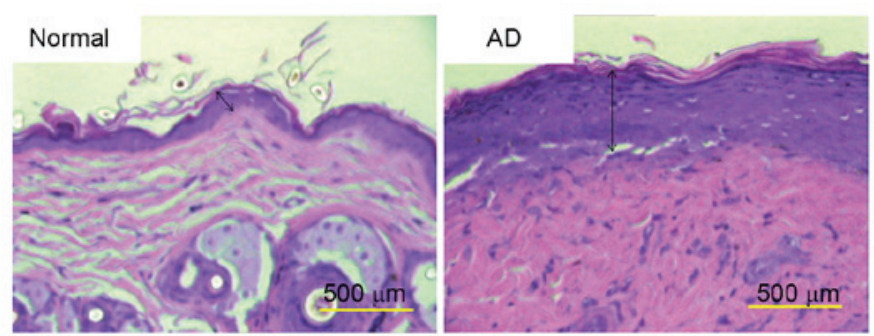

Prednisolone3
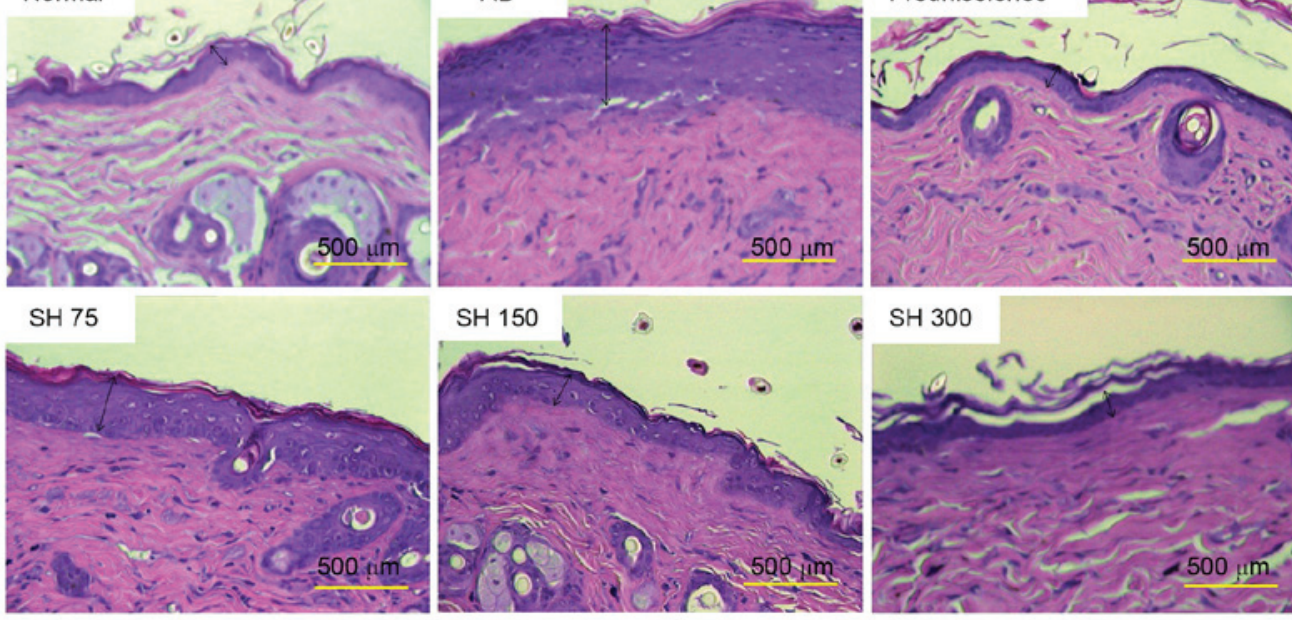

B

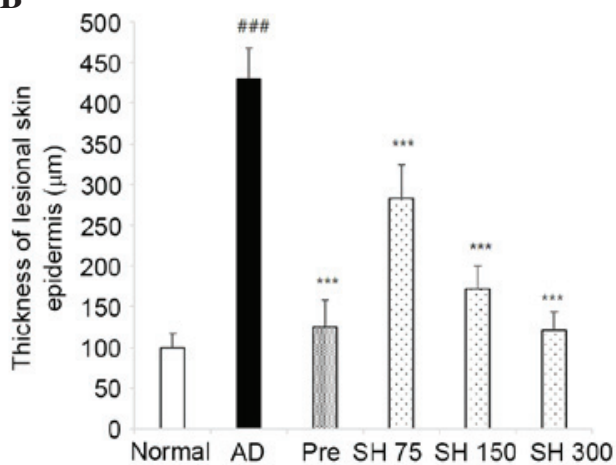

$\mathbf{C}$

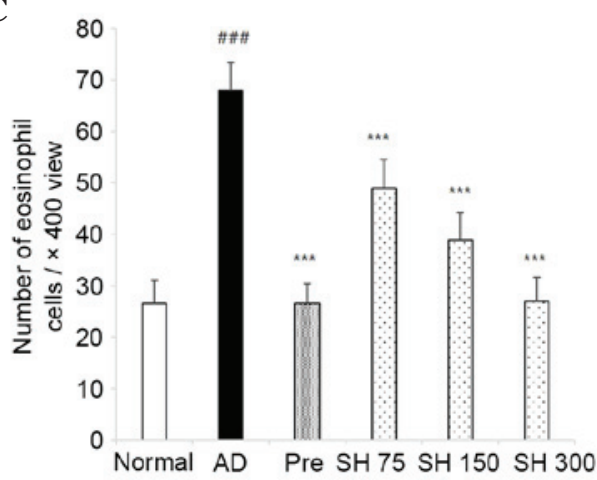

Figure 8. Histological features of atopic dermatitis (AD)-like skin lesions treated with Solanum tuberosum L. cv Hongyoung extract (SH) in NC/Nga mice. The dorsal area of each mouse was sectioned, and hematoxylin and eosin (H\&E)-stained sections were observed under a microscope at a magnification of $\mathrm{x} 400$. (A) H\&E-stained lesional skin of normal, AD, prednisolone (Pre, $3 \mathrm{mg} / \mathrm{kg} \cdot \mathrm{bw}$ ) and SH (75, $150 \mathrm{and} 300 \mathrm{mg} / \mathrm{kg} \cdot \mathrm{bw})$-treated groups. (B) Epidermal thickness and $(C)$ the number of infiltrated eosinophils in four sites chosen at random were counted. Scale bar $=500 \mu \mathrm{m}$. Data are presented as the mean \pm standard error of the mean from six mice per group. ${ }^{\# \#} \mathrm{P}<0.001$, vs. the normal group; ${ }^{* * *} \mathrm{P}<0.001$ vs. the AD group.

ELISA kits. The Th2 cytokines, IL-4 and IL-13, are expressed in the acute stage of AD. The Th1 cytokines, IFN- $\gamma$ and IL-12, are expressed in the chronic stage of AD. As shown in Fig. 6, repeated application of DNCB markedly increased the levels of Th1 and Th2 cytokines in the mice. The cytokine IL- 4 was decreased by $26,30,34$ and $39 \%$ in the prednisolone and $\mathrm{SH}$ extract groups $(75,150$ and $300 \mathrm{mg} / \mathrm{kg})$, respectively. IL-13 was decreased by $42,41,43$ and $57 \%$, respectively. IFN- $\gamma$ was decreased by 64, 62, 64 and 67\%, respectively. IL-12 levels were decreased by $70,47,72$ and $75 \%$, respectively. These results indicate that $\mathrm{SH}$ extract inhibits $\mathrm{Th} 1$ and $\mathrm{Th} 2$ cytokine levels compared with in the negative control group. In AD, increased numbers of Th17 cells and enhanced expression of IL-17 contribute to neutrophil chemotaxis and increased expression of antimicrobial peptides (24). As shown in Fig. 6 , IL-17 was increased in the AD group, and was decreased by $24,27,35$ and $42 \%$ in the prednisolone and SH extract groups $(75,150$ and $300 \mathrm{mg} / \mathrm{kg})$, respectively.

Effects of SH on DNCB-induced mRNA expression of IL-4, $I L-13, I L-5, I L-12, I F N-\gamma$, eotaxin, $C$ - $C$ chemokine receptor (CCR)3, CCR4, IL-17 and monocyte chemoattractant protein (MCP)-1 in NC/Nga mice. The present study investigated the inhibitory effects of $\mathrm{SH}$ extract on the mRNA expression levels of Th1, Th2 and Th17 cytokines, and chemokines in lesional skin. Repeated application of DNCB significantly increased the mRNA expression levels of IL-4, IL-5, IFN- $\gamma$, IL-12, eotaxin-1, CCR3, MCP-1, CCR4 and IL-17 in lesional skin; however, SH inhibited DNCB-induced cytokine and chemokine mRNA expression (Fig. 7). These results indicate that SH treatment may suppress DNCB-induced cytokine and chemokine expression, leading to inhibition of skin inflammation caused by the infiltration of inflammatory cells.

Effects of SH on DNCB-induced AD-like histopathological alterations in $\mathrm{Nc} / \mathrm{Nga}$ mice. After the mice were sacrificed, dorsal and ear skin samples were sectioned, and stained with H\&E and toluidine blue. As shown in Figs. 8 and 9, ear lesions exhibited hyperkeratosis, thickening of the epidermis, and inflammatory cells accumulated within the skin lesions. These symptoms were all suppressed by SH treatment. These results indicate that $\mathrm{SH}$ extract may effectively decrease AD symptoms in NC/Nga mice.

\section{Discussion}

$\mathrm{AD}$ is a chronic relapsing inflammatory, pruritic epidemic disease that affects people worldwide (2). Recent studies have 
A
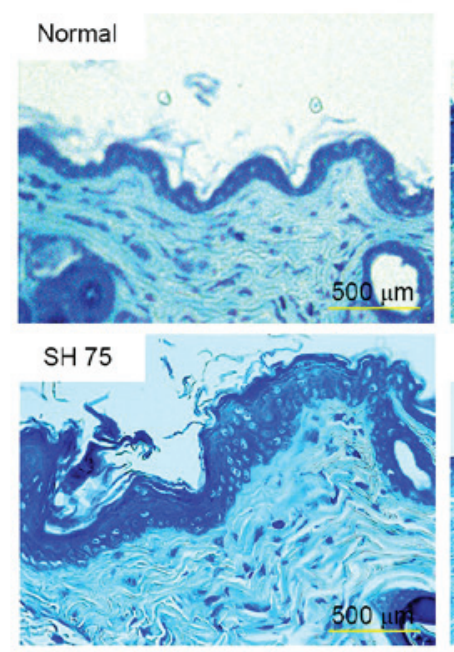

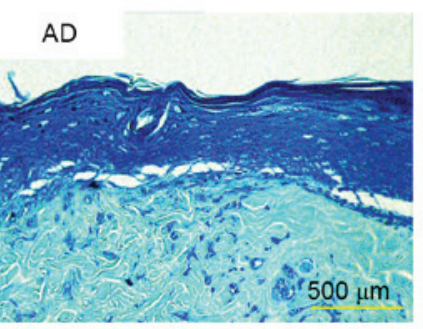

SH 150

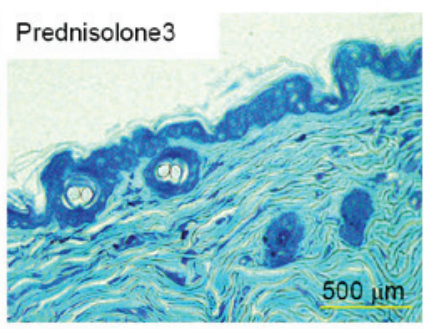

$\mathrm{SH} 300$

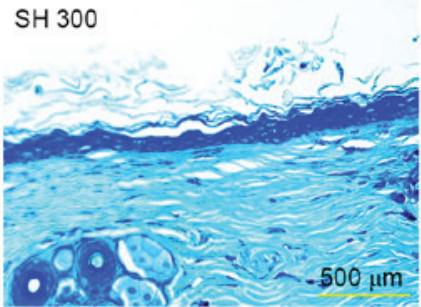

B

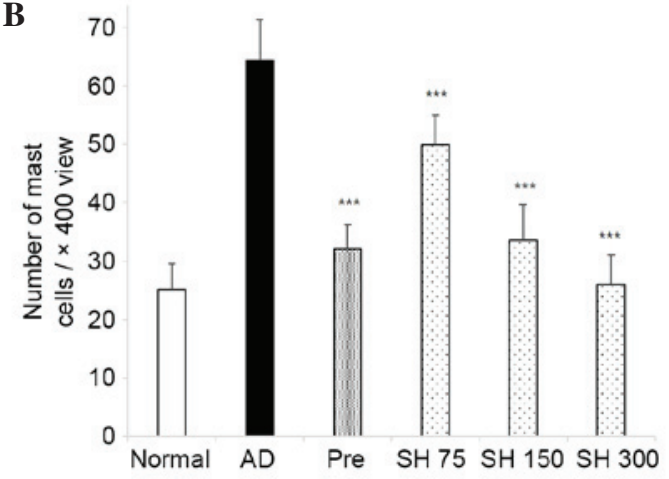

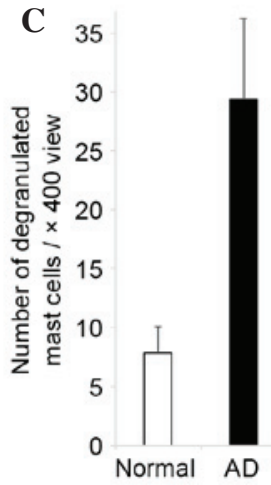

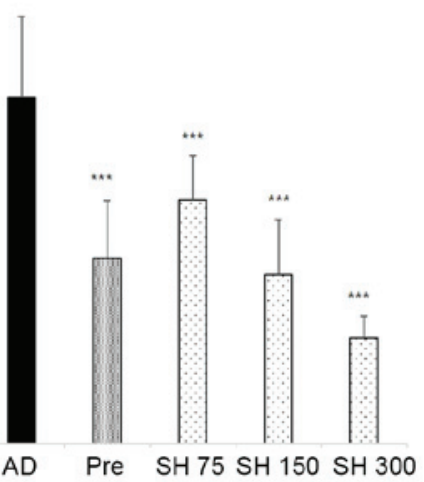

Figure 9. Histological features of atopic dermatitis (AD)-like skin lesions treated with Solanum tuberosum L. cv Hongyoung extract (SH) in NC/Nga mice. The dorsal area of each mouse was sectioned, and toluidine blue-stained sections were observed under a microscope at a magnification of $\mathrm{x} 400$. (A) Toluidine blue-stained lesional skin of normal, AD, prednisolone (Pre, $3 \mathrm{mg} / \mathrm{kg} \cdot \mathrm{bw}$ ) and SH (75, $150 \mathrm{and} 300 \mathrm{mg} / \mathrm{kg} \cdot \mathrm{bw})$-treated groups. (B) Number of infiltrated mast cells and (C) degranulated mast cells in five sites chosen at random were counted. Scale bar $=500 \mu \mathrm{m}$. Data are presented as the mean \pm standard error of the mean from six mice per group. ${ }^{* * *} \mathrm{P}<0.001$, vs. the AD group.

markedly improved our knowledge regarding the immunological mechanisms that underlie the pathogenesis of $\mathrm{AD}(25)$. However, complex mutual associations between the immune system and environmental, genetic and immunological factors remain to be examined (1).

In $\mathrm{AD}$, the existence of high numbers of $\mathrm{CD} 4^{+}$and $\mathrm{CD} 8^{+}$ $\mathrm{T}$ cells has been demonstrated by culturing $\mathrm{T}$ cells from skin biopsies and by immunohistochemistry $(26,27)$. Numerous studies have indicated the role of activated $\mathrm{CD} 4^{+} \mathrm{T}$ cells in AD $(28,29)$. The cutaneous lymphocyte-associated antigen ${ }^{+}$ $\mathrm{T}$ cell infiltrate according to cytokine and chemokine receptor expression has disclosed novel $\mathrm{T}$ helper cell classification (Th1, Th2, Th17 and Treg cell subsets) that play an important role in AD (30). Reduced numbers of regulatory Treg cells, influenced by environmental and genetic factors, predispose individuals to the development of AD in early life (31). AD is characterized by skin lesions that result from dermal inflammation, a characteristic feature of which is a disruption in the immunological balance between Th1 and Th2 cells (9). The Th1/Th2 balance can be identified through the $\operatorname{IgG} 2 / \operatorname{IgG} 1$ ratio, which is a marker for Th1 and Th2 lymphocytes (32). The present study investigated whether SH extract was able to modulate the Th1/Th2 balance and inhibit the development of DNCB-induced dermatitis in $\mathrm{NC} / \mathrm{Nga}$ mice, a condition histologically and clinically similar to human AD. Solanum tuberosum varieties with intense blue-red colored pulp are well-known and widely used in the preparation of traditional dishes of local populations. Potatoes with purple-red flesh are considered good sources of appreciable amounts of phenolic acids, particularly acylated anthocyanins (33). The pigments responsible for the particular color of the tubers reflect their anthocyanin content (16). The major pigment present in SH extract is perelagonidin-3-coumaroyl-rutinoside-5-O-glucoside. This compound is also expressed in other red-flashed potatoes (34). Previous studies have reported that anthocyanins exert anti-inflammatory and anticancer activities $(35,36)$. In the present study, the pathogenesis of DNCB-induced contact hypersensitivity resulted from $\mathrm{T}$ cell-mediated immune responses (37). In DNCB-induced AD, Th2 cytokines are expressed in the acute phase, whereas Th1 cytokines are expressed and contribute to the pathogenesis of AD in the chronic phase (38). In the acute phase, the Th2 cytokines IL-4 and IL-13 mediate the secretion of IgE in B cells (39). Mast cells are stimulated in response to active cross-linking of AD-specific IgE with high affinity cell-surface IgE-receptors, and degranulated mast 
cells release active mediators, including histamine (40). In the chronic phase, Th1 cytokines IL-12 and IFN- $\gamma$ are produced, inducing a local Th1 response and tissue alterations, such as dermal thickening (41). Another feature of $\mathrm{AD}$ is the presence of characteristic inflammatory dendritic cell subtypes in the dermis and epidermis (42). Antigen-presenting cells, such as $\mathrm{CD}_{1} \mathrm{a}^{+}$epidermal dendritic cells, dermal dendritic cells, and monocytes appear to have an important role in $\mathrm{AD}$, and typically express the high-affinity receptor for IgE (FceRI) (43). Stimulation of FceRI on the surface of inflammatory dendritic epidermal cells induces the release of IL-12 and IL-18 (44). These cytokines may contribute to the switch from the initial Th2 immune response in acute AD to the Th1 polarization of $\mathrm{T}$ cells in the chronic phase (44). Keratinocytes of patients with $\mathrm{AD}$ release higher amounts of several proinflammatory cytokines and chemokines, as compared with keratinocytes from non-AD skin (45). Keratinocytes respond to Th1 and Th2 cytokines from T cells (46). The Th1 cytokine IFN- $\gamma$ is one of the most potent keratinocyte-activating factors (47). In keratinocytes, inflammatory chemokines, including $\mathrm{C}-\mathrm{C}$ motif chemokine ligand (CCL)3, CCL4, CCL11/eotaxin-1 and CCL2/MCP-1 have been reported to be associated with AD characteristics and may support leukocyte recruitment (48). The C-C chemokine family adaptive immune responses are induced via dendritic cells, basophils, mast cells, lymphocytes and eosinophils (49). CCL11/eotaxin-1 is a member of the CC chemokines, which is known to be a potent chemoattractant for eosinophils, and induces the pathological responses typically associated with $\mathrm{AD}(50)$. It has previously been demonstrated that CCL11/eotaxin-1 receptor CCR3 expression is induced after IL-2 and IL-4 co-incubation (51). In addition, MCP-1 is a member of the $\mathrm{CC}$ chemokine family, with strong chemotactic activity for lymphocytes $\left(\mathrm{CD} 45^{+}\right)$, eosinophils and monocytes/macrophages (52). MCP-1 also has an essential role in the recruitment and activation of mast cells, leukocytes and other cell types at the site of inflammation (53), and is presumed to be the functional ligand for CCR4, which is also expressed at high levels by activated $\mathrm{T}$ lymphocytes, particularly those of the CD4 subset (54). Therefore, chemokines may have a role in the initiation or triggering of the immune response by facilitating the interaction of $\mathrm{T}$ cells with antigen-presenting cells at sites of inflammation (49).

The present study demonstrated that systemic administration of SH significantly reduced ear thickness, clinical symptoms, and serum IgE levels in DNCB-induced AD-like skin lesions of $\mathrm{NC} / \mathrm{Nga}$ mice, which is comparable to prednisolone. In addition, oral administration of SH extract reduced IgG2a and IgE levels. In the serum of SH-treated mice, IgG2a levels were increased and IgG1 levels were decreased, resulting in a reduced $\operatorname{IgG} 2 / \operatorname{IgG} 1$ ratio, thus indicating that the Th1/Th2 ratio was also reduced. SH extract controls the production of selective Th1, Th2 and Th17-mediated cytokines in DNCB-induced mice. In addition, the present study investigated the mRNA expression levels of AD-related cytokines and chemokines. The skin mRNA expression pattern of Th1, Th2, and Th17-related cytokines and chemokines in the AD-like mouse model used in the present study exhibited slight differences compared with the pattern in human AD skin lesions (55). In the present study, the SH extract-administrated group exhibited decreased Th1, Th2 and Th17 cytokines, and DNCB-induced chemokines (CCR3,
CCR4, MCP-1, CCL11/eotaxin-1). In AD, inflammatory cell infiltration into the skin is a major characteristic. Histologically, hypertrophy, and an accumulation of mast and dendritic cells, occurs in the epidermis and dermis of patients with $\mathrm{AD}(56)$. In the present study, SH extract reduced hypertrophy and infiltration of inflammatory cells, such as mast cells and eosinophils, in the skin. Furthermore, the number of degranulated mast cells was reduced in the $\mathrm{SH}$ extract-treated groups.

In conclusion, the present study demonstrated that $\mathrm{SH}$ extract alleviates atopic symptoms in DNCB-induced NC/Nga mice. In addition, $\mathrm{SH}$ extract reduced $\mathrm{AD}$-related cytokine and chemokine expression, and inflammatory cell accumulation. These results indicated that SH extract may exert anti-AD effects, and be considered a useful treatment for AD.

\section{References}

1. Udompataikul $\mathrm{M}$ and Limpa-o-vart D: Comparative trial of $5 \%$ dexpanthenol in water-in-oil formulation with $1 \%$ hydrocortisone ointment in the treatment of childhood atopic dermatitis: A pilot study. J Drugs Dermatol 11: 366-374, 2012.

2. Amin K: The role of mast cells in allergic inflammation. Respir Med 106: 9-14, 2012.

3. Sampson HA: Atopic dermatitis. Ann Allergy 69: 469-479, 1992.

4. Schneider L, Tilles S, Lio P, Boguniewicz M, Beck L, Lebovidge J, et al: Atopic dermatitis: A practice parameter update 2012. J Allergy Clin Immunol 131: 295-299, 2013.

5. Hashimoto Y, Takaoka A, Sugimoto M, Honma Y, Sakurai T, Futaki $\mathrm{N}$ and Arai I: Itch-associated scratching contributes to the development of dermatitis and hyperimmunoglobulinaemia $\mathrm{E}$ in NC/Nga mice. Exp Dermatol 20: 820-825, 2011.

6. Leung DY and Soter NA: Cellular and immunologic mechanisms in atopic dermatitis. J Am Acad Dermatol 44 (Suppl 1): S1-S12, 2001.

7. Miraglia del Giudice M, Decimo F, Leonardi S, Maioello N, Amelio R, Capasso A, Capristo C and Capristo AF: Immune dysregulation in atopic dermatitis. Allergy Asthma Proc 27: 451-455, 2006.

8. Wierenga EA, Snoek M, Jansen HM, Bos JD, van Lier RA and Kapsenberg ML: Human atopen-specific types 1 and $2 \mathrm{~T}$ helper cell clones. J Immunol 147: 2942-2949, 1991.

9. Szegedi A, Baráth S, Nagy G, Szodoray P, Gál M, Sipka S, Bagdi E, Banham AH and Krenács L: Regulatory T cells in atopic dermatitis: epidermal dendritic cell clusters may contribute to their local expansion. Br J Dermatol 160: 984-993, 2009.

10. Oyoshi MK, He R, Kumar L, Yoon J and Geha RS: Cellular and molecular mechanisms in atopic dermatitis. Adv Immunol 102: 135-226, 2009.

11. Eyerich K, Pennino D, Scarponi C, Foerster S, Nasorri F, Behrendt H, Ring J, Traidl-Hoffmann C, Albanesi C and Cavani A: IL-17 in atopic eczema: Linking allergen-specific adaptive and microbial-triggered innate immune response. J Allergy Clin Immunol 123: 59-66.e4, 2009.

12. Nakae S, Komiyama Y, Nambu A, Sudo K, Iwase M, Homma I, Sekikawa K, Asano M and Iwakura Y: Antigen-specific T cell sensitization is impaired in IL-17-deficient mice, causing suppression of allergic cellular and humoral responses. Immunity 17: 375-387, 2002.

13. Hengge UR, Ruzicka T, Schwartz RA and Cork MJ: Adverse effects of topical glucocorticosteroids. J Am Acad Dermatol 54: 1-15; quiz 16-18, 2006.

14. Yang G, Choi CH, Lee K, Lee M, Ham I and Choi HY: Effects of Catalpa ovata stem bark on atopic dermatitis-like skin lesions in NC/Nga mice. J Ethnopharmacol 145: 416-423, 2013.

15. Ieri F, Innocenti M, Andrenelli L, Vecchio V and Mulinacci N: Rapid HPLC/DAD/MS method to determine phenolic acids, glycoalkaloids and anthocyanins in pigmented potatoes (Solanum tuberosum L.) and correlations with variety and geographical origin. Food Chemistry 125: 750-759, 2011.

16. Mulinacci N, Ieri F, Giaccherini C, Innocenti M, Andrenelli L, Canova G, Saracchi M and Casiraghi MC: Effect of cooking on the anthocyanins, phenolic acids, glycoalkaloids, and resistant starch content in two pigmented cultivars of Solanum tuberosum L. J Agric Food Chem 56: 11830-11837, 2008. 
17. Afaq F, Malik A, Syed D, Maes D, Matsui MS and Mukhtar H: Pomegranate fruit extract modulates UV-B-mediated phosphorylation of mitogen-activated protein kinases and activation of nuclear factor kappa B in normal human epidermal keratinocytes paragraph sign. Photochem Photobiol 81: 38-45, 2005.

18. Suto H, Matsuda H, Mitsuishi K, Hira K, Uchida T, Unno T, Ogawa H and Ra C: NC/Nga mice: A mouse model for atopic dermatitis. Int Arch Allergy Immunol 120 (Suppl 1): S70-S75, 1999.

19. Takano N, Arai I and Kurachi M: Analysis of the spontaneous scratching behavior by NC/Nga mice: A possible approach to evaluate antipruritics for subjects with atopic dermatitis. Eur J Pharmacol 471: 223-228, 2003

20. Mihara K, Kuratani K, Matsui T, Nakamura M and Yokota K: Vital role of the itch-scratch response in development of spontaneous dermatitis in NC/Nga mice. Br J Dermatol 151: 335-345, 2004

21. Livak KJ and Schmittgen TD: Analysis of relative gene expression data using real-time quantitative PCR and the 2(-Delta Delta C(T)) Method. Methods 25: 402-408, 2001.

22. Wesolowski J and Paumet F: The impact of bacterial infection on mast cell degranulation. Immunol Res 51: 215-226, 2011.

23. Lee TY, Kim DJ, Won JN, Lee IH, Sung MH and Poo H: Oral administration of poly-gamma-glutamate ameliorates atopic dermatitis in Nc/Nga mice by suppressing Th2-biased immune response and production of IL-17A. J Invest Dermatol 134: 704-711, 2014

24. Koga C, Kabashima K, Shiraishi N, Kobayashi M and Tokura Y: Possible pathogenic role of Th17 cells for atopic dermatitis. J Invest Dermatol 128: 2625-2630, 2008.

25. Bieber T: Atopic dermatitis. N Engl J Med 358: 1483-1494, 2008

26. Akdis M, Simon HU, Weigl L, Kreyden O, Blaser K and Akdis CA: Skin homing (cutaneous lymphocyte-associated antigen-positive) $\mathrm{CD} 8+\mathrm{T}$ cells respond to superantigen and contribute to eosinophilia and IgE production in atopic dermatitis. J Immunol 163: 466-475, 1999.

27. Akdis CA, Akdis M, Simon D, Dibbert B, Weber M, Gratzl S, Kreyden O, Disch R, Wüthrich B, Blaser K and Simon HU: T cells and $\mathrm{T}$ cell-derived cytokines as pathogenic factors in the nonallergic form of atopic dermatitis. J Invest Dermatol 113 : 628-634, 1999.

28. Kim GD, Kim TH, Park YS, Ahn HJ, Cho JJ and Park CS: Immune response against 2,4-dinitrofluorobenzene-induced atopic dermatitis-like clinical manifestation is suppressed by spermidine in NCNga mice. Scand J Immunol 81: 221-228, 2015.

29. Lin YT, Wang CT, Chao PS, Lee JH, Wang LC, Yu HH, Yang YH and Chiang BL: Skin-homing CD4 ${ }^{+}$Foxp $3^{+} \mathrm{T}$ cells exert Th2-like function after staphylococcal superantigen stimulation in atopic dermatitis patients. Clin Exp Allergy 41: 516-525, 2011

30. Werfel T: The role of leukocytes, keratinocytes, and allergen-specific IgE in the development of atopic dermatitis J Invest Dermatol 129: 1878-1891, 2009.

31. Hinz D, Bauer M, Röder S, Olek S, Huehn J, Sack U, Borte M Simon JC, Lehmann I and Herberth G; LINA study group: Cord blood Tregs with stable FOXP3 expression are influenced by prenatal environment and associated with atopic dermatitis at the age of one year. Allergy 67: 380-389, 2012.

32. Mountford AP, Fisher A and Wilson RA: The profile of IgG1 and $\mathrm{IgG} 2 \mathrm{a}$ antibody responses in mice exposed to Schistosoma mansoni. Parasite Immunol 16: 521-527, 1994.

33. N'Dri D, Mazzeo T, Zaupa M, Ferracane R, Fogliano V and Pellegrini N: Effect of cooking on the total antioxidant capacity and phenolic profile of some whole-meal African cereals. J Sci Food Agric 93: 29-36, 2013.

34. Eichhorn S and Winterhalter P: Anthocyanins from pigmented potato (Solanum tuberosum L.) varieties. Food Research International 38: 943-948, 2005.

35. Han KH, Sekikawa M, Shimada K, Hashimoto M, Hashimoto N, Noda T, Tanaka H and Fukushima M: Anthocyanin-rich purple potato flake extract has antioxidant capacity and improves antioxidant potential in rats. Br J Nutr 96: 1125-1133, 2006.

36. Afaq F, Saleem M, Krueger CG, Reed JD and Mukhtar H: Anthocyanin- and hydrolyzable tannin-rich pomegranate fruit extract modulates MAPK and NF-kappaB pathways and inhibits skin tumorigenesis in CD-1 mice. Int J Cancer 113: 423-433, 2005.

37. Zhang EY, Chen AY and Zhu BT: Mechanism of dinitrochlorobenzene-induced dermatitis in mice: Role of specific antibodies in pathogenesis. PLoS One 4: e7703, 2009.
38. Vestergaard C, Yoneyama H, Murai M, Nakamura K, Tamaki K, Terashima Y, Imai T, Yoshie O, Irimura T, Mizutani $\mathrm{H}$ and Matsushima K: Overproduction of Th2-specific chemokines in $\mathrm{NC} / \mathrm{Nga}$ mice exhibiting atopic dermatitis-like lesions. J Clin Invest 104: 1097-1105, 1999.

39. Kishimoto T and Hirano T: Molecular regulation of B lymphocyte response. Annu Rev Immunol 6: 485-512, 1988.

40. Hussain Z, Katas H, Mohd Amin MC and Kumolosasi E: Efficient immuno-modulation of TH1/TH2 biomarkers in 2,4-dinitrofluorobenzene-induced atopic dermatitis: Nanocarrier-mediated transcutaneous co-delivery of anti-inflammatory and antioxidant drugs. PLoS One 9: e113143, 2014.

41. Niebuhr M and Werfel T: Innate immunity, allergy and atopic dermatitis. Curr Opin Allergy Clin Immunol 10: 463-468, 2010.

42. Wollenberg A, Kraft S, Hanau D and Bieber T: Immunomorphological and ultrastructural characterization of Langerhans cells and a novel, inflammatory dendritic epidermal cell (IDEC) population in lesional skin of atopic eczema. J Invest Dermatol 106 446-453, 1996

43. Bieber T: The pro- and anti-inflammatory properties of human antigen-presenting cells expressing the high affinity receptor for IgE (Fc epsilon RI). Immunobiology 212: 499-503, 2007.

44. Novak N, Valenta R, Bohle B, Laffer S, Haberstok J, Kraft S and Bieber T: FcepsilonRI engagement of Langerhans cell-like dendritic cells and inflammatory dendritic epidermal cell-like dendritic cells induces chemotactic signals and different T-cell phenotypes in vitro. J Allergy Clin Immunol 113: 949-957, 2004.

45. Kasraie S, Niebuhr M, Baumert K and Werfel T: Functional effects of interleukin 31 in human primary keratinocytes. Allergy 66: 845-852, 2011.

46. Meyer N, Zimmermann M, Bürgler S, Bassin C, Woehrl S, Moritz K, Rhyner C, Indermitte P, Schmid-Grendelmeier P, Akdis $\mathrm{M}$, et al: IL-32 is expressed by human primary keratinocytes and modulates keratinocyte apoptosis in atopic dermatitis. J Allergy Clin Immunol 125: 858-865.e810, 2010.

47. Klunker S, Trautmann A, Akdis M, Verhagen J, Schmid-Grendelmeier P, Blaser $\mathrm{K}$ and Akdis CA: A second step of chemotaxis after transendothelial migration: Keratinocytes undergoing apoptosis release IFN-gamma-inducible protein 10 , monokine induced by IFN-gamma, and IFN-gamma-inducible alpha-chemoattractant for T cell chemotaxis toward epidermis in atopic dermatitis. J Immunol 171: 1078-1084, 2003.

48. Homey B, Steinhoff M, Ruzicka T and Leung DY: Cytokines and chemokines orchestrate atopic skin inflammation. J Allergy Clin Immunol 118: 178-189, 2006

49. Sokol CL and Luster AD: The chemokine system in innate immunity. Cold Spring Harb Perspect Biol 7: pii: a016303, 2015.

50. Nakatani T, Kaburagi Y, Shimada Y, Inaoki M, Takehara K, Mukaida N and Sato S: CCR4 memory CD4+ T lymphocytes are increased in peripheral blood and lesional skin from patients with atopic dermatitis. J Allergy Clin Immunol 107: 353-358, 2001.

51. Amerio P, Frezzolini A, Feliciani C, Verdolini R, Teofoli P, De Pità $\mathrm{O}$ and Puddu $\mathrm{P}$ : Eotaxins and CCR3 receptor in inflammatory and allergic skin diseases: Therapeutical implications. Curr Drug Targets Inflamm Allergy 2: 81-94, 2003.

52. Esnault S, Benbernou N, Lavaud F, Shin HC, Potron G and Guenounou M: Differential spontaneous expression of mRNA for IL-4, IL-10, IL-13, IL-2 and interferon-gamma (IFN-gamma) in peripheral blood mononuclear cells (PBMC) from atopic patients. Clin Exp Immunol 103: 111-118, 1996.

53. Conti P, Pang X, Boucher W, Letourneau R, Reale M, Barbacane RC, Thibault J and Theoharides TC: Impact of Rantes and MCP-1 chemokines on in vivo basophilic cell recruitment in rat skin injection model and their role in modifying the protein and mRNA levels for histidine decarboxylase. Blood 89: 4120-4127, 1997

54. Imai T, Baba M, Nishimura M, Kakizaki M, Takagi S and Yoshie O: The T cell-directed CC chemokine TARC is a highly specific biological ligand for CC chemokine receptor 4. J Biol Chem 272: 15036-15042, 1997.

55. Schröder JM and Mochizuki M: The role of chemokines in cutaneous allergic inflammation. Biol Chem 380: 889-896, 1999.

56. Galli SJ, Nakae S and Tsai M: Mast cells in the development of adaptive immune responses. Nat Immunol 6: 135-142, 2005. 